\title{
Procedural and legal issues of the application of the limitation period
}

\author{
Sergey Lazarev* \\ Urals State Law University, Civil Procedure Department, Yekaterinburg, 620137, Russia
}

\begin{abstract}
The article substantiates the procedural and legal nature of the limitation period, due to the possibility of the defendant to defend himself against the claim. The author concludes that the presence or absence of the need for procedural activities to consider the claim depends on the will of the defendant (application) and the application of the statute of limitations by the court. As a general rule, the issue of the application of the limitation period should be decided before the trial and formalized by a court ruling. A court ruling is not required.
\end{abstract}

\section{Introduction}

Recall that traditionally the limitation period is considered, in an objective sense, as a civil institution, a system of legislative norms governing relations related to the period of protection of civil rights (timing, occurrence, etc.), and in a subjective sense as a person's right, whose interests are violated, to use the term to protect violated civil rights [1].

It should be noted that, despite the fact that in most states the statute of limitations is an institution of substantive law, there are countries (USA, Great Britain and Finland) in which the statute of limitations is an institution of procedural law $[2,3]$.

In the domestic doctrine, there is no consensus on the nature of the limitation period. A survey of points of view on this issue was undertaken by P.A. Ilyichev [4]. Without plunging into the discussion on this issue, we note that the application of the limitation of actions outside the process is impossible.

In addition, it is possible to declare the expiration of the limitation period only when the case is considered according to the rules of the court of first instance. The limitation period begins to run simultaneously with the emergence of the right to claim in a specific sense. The statement by the defendant about the expiration of the limitation period is a procedural remedy against the claim [5].

Application of the limitation period terminates the procedural activities of the court. Accordingly, we are in solidarity with the position of A.A. Dobrovolsky, who believed that the limitation period should be considered a complex institution of substantive and procedural law [6].

Below, we will focus on the limitation period in the subjective sense and consider a yard of procedural and legal issues that arise in its application.

\section{Appointment of limitation of actions}

G.F. Shershenevich noted that "the real reason for prescription is that society needs a solid order and any uncertainty of relations that can shake acquired rights, arouses a protest against itself" [7].

In addition, D. I. Meyer pointed to the purpose of the statute of limitations, as the desire of legislation to punish the subject of law for his negligence towards him: "... the field of law is not a haven of carelessness, but society has the right to demand from every citizen that he cares about his rights, because in the totality of a citizen's rights his public personality is expressed, and therefore, if a person does not care about the exercise of his right, if he allows another to enjoy his benefits then the person deserves to be deprived of this right; this is a morally just punishment for him" [8].

The stability of civil turnover, as a basis for limitation of actions, is indicated in modern literature [1; 29-31, 35].

According to the position of the Constitutional Court of the Russian Federation, the institution of limitation of actions in civil law aims to streamline civil circulation, create certainty and stability of legal ties, discipline their participants, promote compliance with business contracts, ensure timely protection of the rights and interests of the subjects of civil legal relations [9].

We believe that some of the above judgments are controversial. So, the existence of a limitation of actions, if we consider it as an opportunity not to fulfill obligations after a certain time, hardly streamlines civil circulation and creates certainty and stability of legal ties, and certainly does not discipline their participants to timely fulfill obligations and comply with business contracts. On the contrary, these goals are achieved by the inevitability of judicial protection of violated rights. If a participant in a civil turnover knew that in any case it

Corresponding author: s.v.lazarev@usla.ru 
would be necessary to fulfill the obligations assumed, regardless of the period of default, then, perhaps, this would rather lead to the stability of the fulfillment of obligations.

In addition, the limitation period could have the purpose of timely protection of the rights and interests of subjects of civil legal relations or would serve as a punishment if a pre-emptive period for judicial protection was established. However, in contrast to the limitation period, which is recognized as "the boundary of the existence of subjective substantive law" [10], the expiration of the limitation period does not terminate the substantive law. Thus, the fulfillment of an obligation upon the expiration of the limitation period does not entail unjust enrichment on the creditor's side and does not endow the debtor with the right to claim what has been fulfilled. In this case, it does not matter whether at the time of execution the debtor knew about the expiration of the limitation period (clause 1 of article 206 of the Civil Code of the Russian Federation).

Let us assume that the main purpose of the limitation period is the possibility of administering justice, stimulating discipline to protect violated rights. S.V. Sarbash reasonably notes in this regard: "Consideration by courts of extremely suppressed disputes entails a significant risk of unfair court decisions, which is at odds with the very meaning of justice. Many defendants, being forced to defend themselves against a crushed claim, would find themselves in a very difficult position, not finding the necessary evidence to refute the possibly unfounded claim" [11]. The Constitutional Court of the Russian Federation also notes in this regard that "the absence of reasonable time limits for the compulsory protection of violated civil rights would lead to an infringement of the legally protected rights and interests of the defendants and third parties, who could not always take into account in advance the need to collect and preserve information relevant to the consideration of the case and facts" [9].

Thus, upon submission to the court of a crushed demand, the legal interest of the claimant collides with the public interest (the possibility of making a lawful and well-grounded court decision, i.e., to maintain law and order) and the private legal interest of the defendant (the possibility for him to defend himself against the crushed demand). In this case, the implementation of the public interest in this case depends on the implementation of the private interest of the defendant. If the defendant does not act (does not declare the application of the limitation of actions), then thereby he confirms the possibility of making a legal decision of the court (the possibility of realizing the public interest). By refusing to apply the statute of limitations and striving to protect his legal interest, the defendant thereby retains in the eyes of justice the value of the legal interest of the claimant.

On the contrary, the defendant, claiming the expiration of the limitation period, as a rule, is guided by his own personal interest, and does not at all think about the interests of justice. However, it is necessary to understand that by refusing the claimant in the claim, the court does not provide judicial protection to the substantive right of the defendant, who in reality may be an offender [12]. F.K. von Savigny reasonably noted that the limitation period may contribute to the enrichment of the defendant. The application of the limitation period entails a refusal to protect the legal interest of the claimant. So, when applying the limitation period for a vindication claim, the court does not check the legality of the defendant's ownership of the property and does not legalize the defendant's legal title by refusing the claimant in the claim.

In other words, the institution of the statute of limitations does not at all pursue the goal of releasing the defendant from obligations with the expiration of the statute of limitations or punishing the claimant for a long failure to file a claim. The institution in question is aimed at the possibility of realizing the defendant's right to respond to the claim and, accordingly, at the possibility of making a lawful and well-grounded court decision. The application of the limitation period entails the loss of the value of the legal interest of the claimant for the court considering the case due to the impossibility of ensuring fair justice.

Thus, the purpose of the institute of limitation of actions is to determine the possibility of administering justice in a particular case, depending on the ability of the defendant to defend himself against the brought claim, that is, the presence or absence of the need for procedural activities to consider the claim depends on the will of the defendant (application) and the application of the limitation by the court.

\section{The stage of the process at which the defendant's application for missing the statute of limitations must be considered}

According to of paragraph 2 of Art. 199 of the Civil Code of the Russian Federation, clause 15 of the Resolution of the Plenum of the Supreme Court of the Russian Federation of 09/29/2015 N 43 "On some issues related to the application of the norms of the Civil Code of the Russian Federation on the limitation period", in the presence of an application from the appropriate person about the expiration of the limitation period and the absence of grounds for it restoration to the individual claimant 1) investigation of other circumstances of the case may not be carried out; 2) the expiration of the limitation period is the basis for refusal to satisfy the claim.

According to paragraph 6 of Art. $152 \mathrm{G}$ of the Civil Procedure Code of the Russian Federation, in a preliminary court session, the defendant's objection regarding the claimant's omission of the statute of limitations for the protection of rights and the period of going to court established by federal law may be considered. When establishing the fact of admission without valid reasons of the limitation period or the period for applying to the court, the judge decides to dismiss the claim without examining other factual circumstances in the case. The court decision can be appealed. 
S.V. Sarbash believes that "in the same way this issue should be resolved in the arbitration process" [11; 877]. This proposal finds a positive response from some proceduralists. For instance, in relation to paragraph 6 of Art. 152 of the Civil Procedure Code of the Russian Federation, I.V. Reshetnikova points out that "this useful and necessary norm fits well into the model of the new Arbitration Procedural Code of the Russian Federation" [13]. G. D. Uletova also believes that it is possible to use this approach in the arbitration process [14]. E.I. Nosyreva believes that the norm of Part 6 of Art. 152 of the Civil Procedure Code of the Russian Federation significantly simplifies and accelerates proceedings in a court of general jurisdiction, saves judges from unnecessary work, and arbitration proceedings loses in this regard [15]. D.G. Filchenko also believes that it is necessary to transfer this provision to the Arbitration Procedure Code of the Russian Federation [16].

However, there is another position. M. L. Skuratovsky draws attention to the fact that the complexity of the legal structure of the application of the limitation period "does not allow in many cases to resolve this issue in a preliminary meeting, and the introduction into the Arbitration Procedure Code of the Russian Federation of a norm similar to the norm of Part 6 of Art. 152 of the Code of Civil Procedure of the Russian Federation, may lead to a significant increase in the number of judicial errors" [17]. A number of scholars believe that the provision of Part 6 of Art. 152 of the Code of Civil Procedure of the Russian Federation is a mistake of the legislator, which must be corrected, and not aggravated [18, 19]. In this case, the following arguments are given: 1) The adoption of a decision at the stage of the preliminary court session violates the principle of discretion: the will and interest of the parties are absolutely not taken into account in this situation. 2) By appealing to the court and paying for the process, the claimant, who missed the statute of limitations or the term for going to court, nevertheless, counted on a fullfledged trial, knowing that, according to the law, the process could not be terminated without his will. 3) The movement of the case according to a simplified procedure (order proceedings, proceedings in absentia) is also possible only with the consent of the claimant (applicant). However, in this case, the claimant expects an unpleasant surprise: a truncated process with a decision to dismiss the claim without trial and without revealing the claimant's consent to simplification, since the law (part 6 of article 152 of the Code of Civil Procedure of the Russian Federation) does not require this.

Accordingly, one should consider the arguments of supporters and opponents of the study of the issue of the expiration of the statute of limitations before the trial.

When examining the issue of the expiration of the limitation period in the preliminary court session, the interest of both parties in the fact that the process will be effective is taken into account. There is no need to waste the time and effort of the court and the parties, to appoint a trial, to investigate other evidence, initially understanding the futility of all these actions. In addition, in this case, the interests of other persons who are awaiting trial, that is, the public interest, must also be taken into account. The claimant's calculations for a fullfledged trial cannot be taken into account, since the court is not a theater in which the actors must work out the money paid for the tickets. Finally, the application of the limitation period is not a simplification of the process, but its exclusion, the impossibility of continuing.

It is well known that the exclusion of the process is possible in cases where there are no prerequisites for the right to claim or non-compliance with the conditions for its implementation. At the same time, as noted above, when applying the limitation period, the circumstances associated with its expiration are investigated, and when the corresponding factual composition is established, a decision is made to refuse to satisfy the claims.

Finally, the argument about the complexity of the legal structure of the application of the limitation period can be taken into account by giving the judge the right to resolve the issue of the application of the limitation period both in the preliminary and in the main court session.

We believe that the application of the limitation period should be flexible. For example, in the literature it is noted that "a judge should not succumb to the temptation to make a judicial decision in a preliminary court session in the case when the claimant presents evidence of a compelling reason for missing the limitation period and (or) the statutory period for applying for judicial protection" [20], i.e. if necessary, research and assess the relevant circumstances.

At the same time, in cases where it is obvious that the limitation period has been missed for the court and other persons and the application of the limitation period has been declared by the party, we believe that there is no transfer of the decision of this issue to court proceedings solely for the purpose of compliance with formal requirements.

Thus, we believe that the issue of the application of the limitation period in most cases is reasonably resolved before the trial.

\section{Registration of the application of the limitation period}

The lack of legal interest entails the end of the process without a court decision.

At the same time, the current legal regulation (clause 2 of Art. 199 of the Civil Code of the Russian Federation, clause 15 of the Resolution of the Plenum of the Supreme Court of the Russian Federation dated 09/29/2015 N 43 "On some issues related to the application of the norms of the Civil Code of the Russian Federation on the limitation period") proceeds from the need for a court to issue a decision to dismiss the claim in connection with the application of the limitation period.

In connection with this, the question of how justified the approach implemented in the law is, requires discussion.

A possible argument that, when applying the limitation period, the court refuses to protect the 
claimant's rights is countered by the fact that if the claim is refused, judicial protection is also denied, but the court's ruling is accepted.

The reason why, when applying the statute of limitations, the court decides to dismiss the claim, we believe, is the need to study the actual composition of the pass of the statute of limitations (expiration of the term, statement of expiration of the term, the absence of an application from the individual claimant on the restoration of the term, or the groundlessness of this statement etc.).

The application of the limitation period is primarily a fact of procedural law, since it makes the further process impractical. Accordingly, clause 15 of the Resolution of the Plenum of the Supreme Court of the Russian Federation dated 09/29/2015 N 43 "On some issues related to the application of the norms of the Civil Code of the Russian Federation on the limitation period" provides that when applying the statute of limitations, the court has the right to refuse to satisfy the claim only on these motives, without examining other circumstances of the case. This does not exclude the possibility of considering the case on the merits. Some courts really, out of striving for greater stability of the judicial act adopted by them, in the event of its appeal, choose this tactic, guided by the fact that "the fallacy of one motive does not discredit another motive, each of which is an independent basis for refusing a claim" [11; 882].

To establish procedural facts in a case, the court not only has the right, but is obliged to examine the evidence. For example, the question of restoring the deadline for filing an appeal is decided by the court when it is accepted. However, this does not mean that the court of appeal is deprived of the opportunity to return to this issue later and in the event of an unreasonable restoration of the time limit, terminate the proceedings on the appeal or, upon a reasonable restoration of the time limit, continue the consideration of the complaint on the merits. Meanwhile, both when accepting an appeal and later, the court must examine the relevant evidence. In addition, the discussion of the validity of restoring the deadline for filing an appeal in the court session is carried out in an adversarial procedure.

Next, we turn to the cases of adjudication. In the Russian doctrine, there is no unity regarding the essence of the court decision, which is defined by various scholars 1) as an authoritative confirmation of a controversial legal relationship and turning it into an indisputable generally binding rule of behavior, 2) as confirmation of the substantive legal relationship that actually exists between the parties and its protection, 3) as confirmation of the right to compulsory execution of the claim, adjudged by the court [21-24]. One way or another, the above positions are reduced to the confirmation of the right based on the results of establishing the circumstances that are part of the subject of proof in the case as a whole.

As you know, the doctrine distinguishes between general and local subjects of proof. For instance, I.V. Reshetnikova notes that "the local subject of proof is determined by procedural legislation for the performance of certain procedural actions or for the revision of a judicial act" [25]. Accordingly, the general subject of proof is the circumstances that are relevant to the consideration and resolution of the case on the merits.

Let us recall that according to the classification of facts proposed in the 19th century [26], which has not lost its significance at the present time [27], several groups of facts are established during the consideration of the case: 1) legal-producing facts; 2) facts of active and passive legitimation; 3 ) the facts of the reason for the claim.

For the application of the limitation period, the establishment of these facts is not required. The case is not considered on the merits.

In this regard, we do not support the approach set out in clause 15 of the Resolution of the Plenum of the Supreme Court of the Russian Federation dated 09/29/2015 N 43 "On some issues related to the application of the rules of the Civil Code of the Russian Federation on the limitation period", according to which it is required to establish the proper character of the defendant when he declares that the claimant has missed the limitation period. The person against whom the claim is filed can declare that the statute of limitations has been missed (part 3 of article 44 of the Arbitration Procedure Code of the Russian Federation). In the event of the expiration of the limitation period, the process for this person should be terminated without finding out whether he is in any relationship with the claimant, since there is no prejudicial nature either for the claimant or for the proper defendant when subsequently filing a claim against the latter such a judicial act will not have.

Similarly, the issue of the application of the limitation period at the request of a third party should be resolved. We would like to remind that according to paragraph 5 of clause 10 of the Resolution of the Plenum of the Armed Forces of the Russian Federation of 09/29/2015 N 43 "On some issues related to the application of the norms of the Civil Code of the Russian Federation on the limitation period", a statement on the omission of the limitation period can be made by a third party if, in case of satisfaction of the claim against the defendant it is possible that the defendant may file a recourse claim or a claim for damages against a third party. In the literature, this position is reasonably criticized on the grounds that it "on the contrary to the principle of the dispositiveness of the civil process and the autonomy of the will of civil law, enables a third party to invade relations in which it does not participate (between the claimant and the defendant)" [28]. Earlier, a similar point of view was expressed by S.V. Sarbash $[11 ; 880]$.

Accordingly, we come to the conclusion that the resolution of the issue of the application of the limitation period may be a court ruling, and not just a court decision. A judgment is required when the case is considered on the merits.

V.M. Zhuikov, recognizing Part 6 of Art. 152 of the Code of Civil Procedure a very useful innovation that allows significantly accelerating the process, gives the following answer to the question of how a judge should 
act in a preliminary court session, if he admits that the limitation period (appeal to the court) either has not been missed at all, or has been missed for a good reason and is subject to restoration: "In this situation, the judge must make an appropriate decision (to establish the fact that the time limit has not been missed or to restore the time limit), since these circumstances relate to the merits of the dispute and therefore cannot be established by determination; after that, the judge appoints the case to the proceedings in the court session, during which other circumstances relevant to the case are clarified and a decision is made on the dispute as a whole. With this approach, appeals against decisions made to a court of second instance should be carried out simultaneously, i.e. after considering the case on the merits in the court session" [29]. Further, the author compares this situation with the one that is regulated in Art. 160 of the Arbitration Procedural Code of the Russian Federation, allowing the arbitration court to consider the case in separate court sessions [29].

Indeed, the consideration of the case should continue if the court concludes that the limitation period has not expired or there are grounds for its restoration. However, we believe that in the case described above there is no need for a court decision, a court ruling is sufficient. Since we came to the conclusion that it is possible to apply the limitation of actions by a court ruling, the question should be answered in the same way in this case. In addition, we consider the issuance of a court decision on the refusal to apply the statute of limitations, and under the current legal regulation, is unnecessary: the court does not draw any conclusions on the merits of the dispute. However, we believe that the silence of the court on this issue is also admissible. Investigation of the circumstances included in the subject of proof in the case as a whole does not necessarily indicate the rejection of an application for missing the statute of limitations. As noted above, in non-obvious cases of the expiration of the limitation period, its application can be only one of the motives for refusing the claim. Sometimes this is seen as procedural economy. For instance, if the court of the cassation instance disagrees with legal qualifications and the application of the limitation period when establishing the factual circumstances, the court has the right to apply the correct norm of substantive law and resolve the dispute without sending the case for new consideration.

Concluding the consideration of procedural and legal issues on the application of the statute of limitations, let us pay attention to one more circumstance. We support the proposal set out in the Concept of a unified Civil Procedure Code on the introduction of the estoppel doctrine [30]. However, we propose to extend its effect not only to the objections of the defendant about the lack of competence (lack of jurisdiction) or lack of jurisdiction of the case, but also to his other procedural and legal objections, in particular to the statement about missing the limitation period.

Our proposal is conditioned by the fact that, on the one hand, as noted above, the limitation period protects the interests of the defendant, if possible, to prove his innocence when filing suppressed claims. On the other hand, the defendant is subject to the requirements for the fair use of his procedural rights (Article 41 of the Arbitration Procedure Code of the Russian Federation) and procedural risk (Article 9 of the Arbitration Procedure Code of the Russian Federation). Failure to declare the expiration of the limitation period within a reasonable period of time entails the procedural activity of the court and other persons participating in the case in preparation for the trial. Just as the statute of limitations should discipline the claimant in timely filing a claim, so the term for objection to the application of the statute of limitations should stimulate the defendant to promptly file a claim.

Thus, the resolution of the issue of the application of the limitation period can be formalized not only by a court decision, but also by a court ruling.

\section{Conclusion}

Consideration of the above procedural and legal issues related to the application of the statute of limitations allows drawing the following conclusions:

- the purpose of the institution of limitation of actions is to determine the possibility of administering justice in a particular case, depending on the ability of the defendant to defend himself against the brought claim, that is, the presence or absence of the need for procedural activities to consider the claim depends on the will of the defendant (application) and the application of the limitation by the court;

- the issue of the application of the limitation period in most cases should be resolved before the trial.

- the resolution of the issue of the application of the limitation period can be formalized not only by a court decision, but also by a court ruling.

\section{References}

1. M.Ya. Kirillova, P.V. Krasheninnikov, Terms in civil law. Limitation of actions. 3rd ed. (Statut, Moscow, 2016) p. 30.

2. L.A. Luntz, Private international law course. In 3 volumes. Vol. 1 (Spark, Moscow, 2002) pp. 247-248

3. M.M. Boguslavsky, Private International Law: Textbook. 5th ed. (Jurist, Moscow, 2005) p. 97.

4. P.A. Ilyichev, Some issues of determining the legal nature of the limitation period, Actual problems of Russian law, 2, 151-155 (2013)

5. D.A. Gribkov, Limitation of actions and terms of going to court in civil proceedings (Moscow, 2009) p. 8.

6. A.A. Dobrovolsky, The main problems of the form of claim for the protection of rights, p. 92.

7. G.F. Shershenevich, Selected works, vol. 5: Textbook of Russian civil law (Statut, Moscow, 2017) p. 191.

8. D.I. Meyer, Russian civil law (Lan, St. Petersburg, 2014) p. 276. 
9. Determination of the Constitutional Court of the Russian Federation of 03.11.2006 N 445-O.

10. M.A. Gurvich, Preventive terms in Soviet civil law (Moscow, 1961) p. 25.

11. A.G. Karapetov (ed.), Transactions, representation, limitation of actions: article-by-article commentary to articles 153-208 of the Civil Code of the Russian Federation (M-Logos, Moscow, 2018) pp. 862-863 (chapter author: S.V. Sarbash).

12. F.K. fon Savigny, The system of modern Roman law: In 8 volumes. Vol. II (Statut, Moscow; Center for the Study of Law, Odessa, 2012) p. 532.

13. I.V. Reshetnikova, Forms of optimization of the arbitration process, Arbitration practice, 10, 56 (2005)

14. G.D. Uletova, The concept of preparing a case for trial in the Code of Civil Procedure of the RSFSR in 1923, the Code of Civil Procedure of the RSFSR in 1964 and the Code of Civil Procedure of the Russian Federation in 2002: Comparative analysis, Novels of civil procedural law: Materials of the scientificpractical conference dedicated to the 80th anniversary of M.S. Shakaryan (N.A. Gromoshina, ed.) (Moscow State Law Academy, Moscow, 2004) p. 51.

15. E.I. Nosyreva, The stage of preparing the case for trial: a comprehensive and comparative analysis of the norms of the Code of Civil Procedure of the Russian Federation and the Arbitration Procedure Code of the Russian Federation, Modern doctrine of civil, arbitration and enforcement proceedings. Theory and Practice: Coll. scientific articles, p. 313.

16. D.G. Filchenko, Preparation of the case for trial: the position of the new Arbitration Procedure Code of the Russian Federation, in: Tribune of young scientists: Proceed. Issue 4. New procedural legislation of the Russian Federation: novels, dignity and contradictions (Yu.N. Starilova, ed.) (Voronezh, 2003) Part 2, p. 187.

17. M.L. Skuratovsky, Preparation of the case for trial in the arbitration court of the first instance (Walters Kluver, Moscow, 2007) p. 141.

18. N.A. Gromoshina, Is the preliminary hearing a simplification of the process? Concept for the development of the judicial system and the system of voluntary and compulsory execution of decisions of the Constitutional Court of the Russian Federation, courts of general jurisdiction, arbitration courts, arbitration courts and the European Court of Human Rights: Proceedings (SPb., Krasnodar, 2007) pp. 333-336.

19. Ya.Kh. Bekov, Preparation of a case for trial in civil proceedings: monograph (Walters Kluver, Moscow, 2010) $176 \mathrm{p}$.

20. N.P. Afanasyeva, Preparation for trial: novellas and problems, Modern law, 8 (2005)

21. The course of the Soviet civil procedural law, vol. 2, pp. 197-205.

22. V.M. Semenov, Theoretical problems of the court decision, in: Brief anthology of the Ural procedural thought, pp. 569-578.

23. N.A. Chechina, The rule of law and the court decision, in: Selected works on civil procedure, pp. 144-156.

24. T.V. Sakhnova, Civil Procedure Course, 2nd ed., (Statut, Moscow, 2014) p. 461.

25. I.V. Reshetnikova, Proofing in civil procedure: a teaching aid for bachelor's and master's degrees. 7th ed. (Yurayt Publishing House, Moscow, 2019) p. 54.

26. V.M. Gordon, The basis of the claim as part of the amendment of the claim (Yaroslavl, 1902) pp. 203204.

27. I.V. Reshetnikova, Evidence course in Russian civil proceedings (Norma; Infra-M, Moscow, 2000) p. 56

28. M.A. Fokina (ed.), Evidence Law Course: Civil Procedure, Arbitration Procedure (Statut, Moscow, 2014) pp. 128-136.

29. N.V. Tololaeva, Passive solidarity obligations: Russian approach and continental European tradition: monograph (Statute, Moscow, 2020) p. 91

30. V.M. Zhuikov, Judicial Reform: Problems of Access to Justice (Statut, Moscow, 2006) pp. 64-65.

31. The concept of a unified Civil Procedure Code of the Russian Federation (Statut, Moscow, 2015) p. 31 